\title{
BRAND ENGAGEMENT THROUGH SOCIAL MEDIA
}

\section{RASHMI $^{1} \&$ AARTI DEVESHWAR ${ }^{2}$}

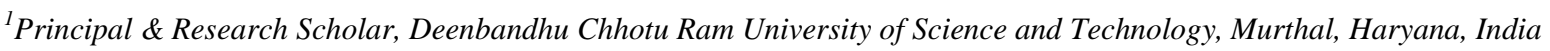

${ }^{2}$ Assistant Professor, Deenbandhu Chhotu Ram University of Science and Technology, Murthal, Haryana, India

Brand Engagement is a significant association between a client and a brand. It is generally utilized as a metric that estimates collaborations among clients and your items, administrations, conditions and correspondences. Social media is a PC based innovation that encourages the sharing of thoughts and data and the working of virtual systems and networks. It is critical to methodically see how particular components of internet based life, implying and speaking to conduct signs of Brand Engagement. There are various dimensions (Conversions, Responsiveness and Clicks/Impression) of social media develop with regards to Brand Engagement. The Brand must connect with crowds substantially. Now a day's clients due associated with the brand through social media. Brand Engagement is fruitful when a man frames a passionate connection to a brand. This paper is Review paper to examines the past literature on brand engagement through social media.
\end{abstract}

KEYWORDS: Social Media, Brand Engagement, Social Media Marketing, Customer Engagement \& Users

Received: Apr 07, 2019; Accepted: Apr 27, 2019; Published: May 16, 2019; Paper Id.: IJCMSJUN201912

\section{INTRODUCTION}

In the advanced universe of business, where administrations and encounters are exchanged as obtrusive as physical merchandise and items, brands have come to imply an arrangement of affiliations that we, as buyers and representatives, make, connected to an arrangement of conveyed guarantees (IAN P.BUCKINGHAM).

Brand Engagement portrays the connection between the guarantee made by an association and the unrestrained choice of people, be they, workers or clients.

Brand Engagement is essentially around three things.

- Understanding the center qualities that the association remains for

- Understanding the necessities of clients, representatives, and partners that these qualities satisfy

- Conveying a progression of guarantees successfully, properly and unequivocally to both the inner and outside partners

Social brand commitment is important association, creation and correspondence between one customer and at least one other customers, utilizing brand or brand-related dialect, pictures and implications. You can't have social brand commitment in disconnection( Kozinets, Robert V.(2014). Commitment require not be entirely about monetary exchange, either. Social brand commitment can happen when the brand is a VIP, a thought, a reason, a goal, a nation of beginning, a nationality or even an action or side interest. With social brand commitment, the relationship enlarges from individual brand to individual brand. 
Brand Engagement and Social Media utilizing techniques to collaborate with their clients. Social Media have changed the manners in which business interface with their client.

Brand Engagement via web-based networking media originates from a multi-disciplinary hypothetical viewpoint - including promoting, human science (Bourdieu, 1986), brain science (Achterberg et al., 2003), and data frameworks (Millen \&Patterson, 2002) - and from showcasing practice (Weinberg \&Pehlivan, 2011). The down to earth establishment of brand commitment via web-based networking media draws from an idea known as "social cash," the degree to which individuals share mark related data with others as a feature of their ordinary social lives. The essential hypothetical establishment of brand commitment via web-based networking media starts from Bourdieu's social capital hypothesis, which recommends that interpersonal organizations have a scope of significant worth, and are reliant upon system size, and intuitiveness (Bourdieu, 1986).

Supplementing this profession, and underscoring the significance of intuitiveness, research in brain science and data frameworks perceives the significance of empowering commitment in social settings (i.e. contribution with social exercises and collaborations) in, for example, online network systems (Zhang et al., 2011, Achterberg et al., 2003; Millen \&Patterson, 2002).For model, Zhang et al. (2011) locate that social commitment, characterized as "the responsibility of a part to remain in the gathering and communicate with different individuals" fortifies social personalities and also, social capital with the affordances of Facebook. Furthermore, Millen \&Patterson (2002) propose that making on the web components that encourage discussions additionally empowers intelligence. Reliable with this work, mark commitment via web-based networking media expands the handy utilization of social cash by catching how buyers cooperate with different shoppers and brands in examining a brand in online social stages. Formally, and paralleling past commitment inquire about, we characterize mark commitment as the clients' social appearance toward a brand - past buy - coming about because of motivational drivers, which is caught through the intuitive practices among shoppers \& brands. While we perceive that this definition applies to both on the web and disconnected settings, We attract particular regard for brand commitment via web-based networking media which catches the degree to which individuals utilize internet based life to draw in with brands and cooperate with different customers as a recognize aspect of their regular daily existences. 


\section{Dimensions of Social Media}

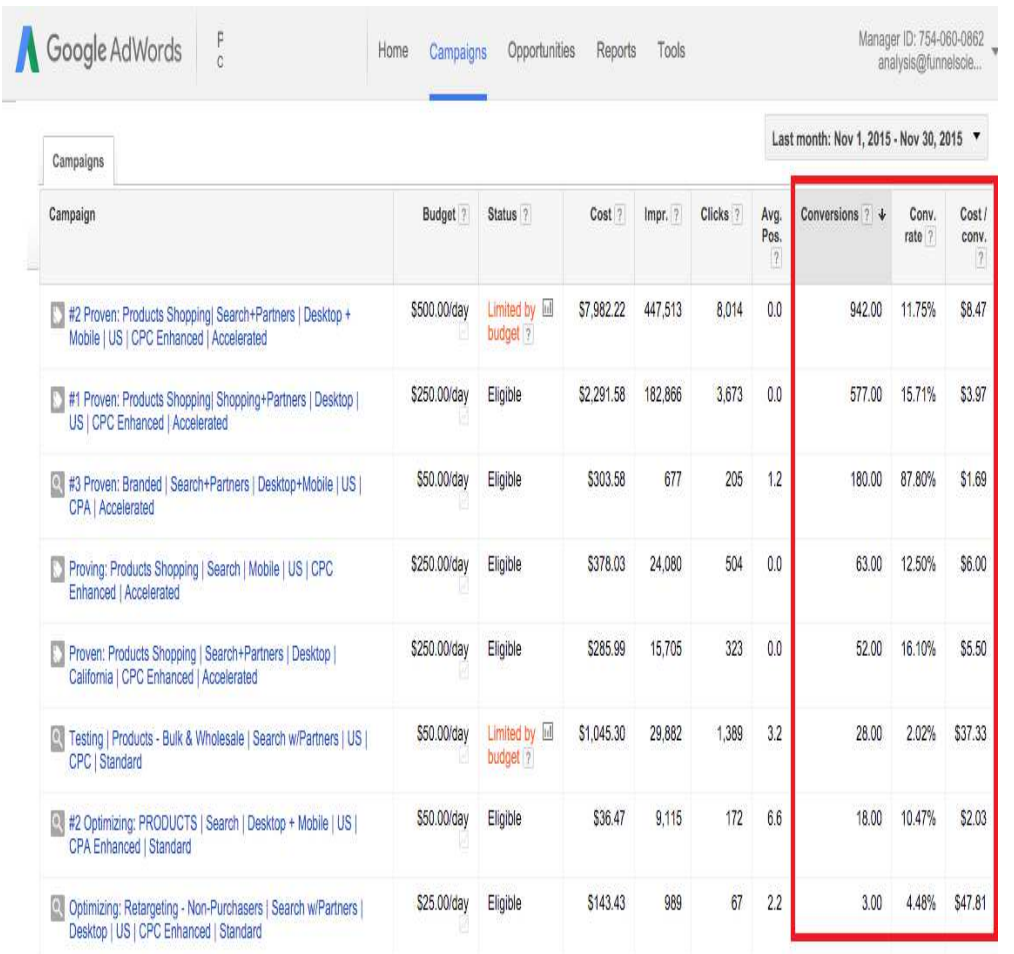

Figure 1

Conversions-Its shows you what happens after customer clicks on ads whether download you they purchased a product, signed up for your newsletter, called your business or download your app.

Responsiveness - Brands are always active in social media. They response the customers.

Clicks/Impression - The no. of times your post/ad has been shown.

\section{Theoretical Background}

Promoting writing has shown that the Internet has on a very basic level changed the manner in which customers produce and get utilization related data. Specifically, customers depend on different Internet-based data sources to settle on buy choices (Anderson and Palma, 2012; Ghose et al., 2014), including utilizing social media platform brand related substance with others (Xiang and Gretzel, 2010), and utilizing web search tools to acquire mark related information(Xiang et al., 2008). Subsequently, firms have progressively put resources into numerous internet promoting channels, including online life and web crawler publicizing. Research likewise recommends that the connection between internet based life and web indexes is developing by the way one impacts the other (Blackshaw and Nazzaro, 2006; Gretzel, 2006; Xiang \&Gretzel, 2010). In this manner, the significant objective of this investigation is to explore how mark commitment via web-based networking media impacts the viability of internet searcher promoting.

Next, we talk about brand commitment via web-based networking media, trailed by an exchange on how three measurements of brand commitment via web-based networking media (i.e. alliance, discussion, and responsiveness) are related with web crawler commercial execution. 


\section{Value of Engagement}

Social media is an engagement channel. The essential motivation to be via social media will be at assemble your image through engagement. Numerous organisations are as of now doing this fortifying their image through social media. A few brands like- (star bucks and Nike). Help their clients rapidly resolve issues through social brand.

Social is a path for us to manufacture trust in the brand by exhibiting our identity in with them, motivate them and answer their inquires rapidly. People use social media to reach brands

According to past survey an ever increasing number of individuals are utilizing social media to get assistance from brands

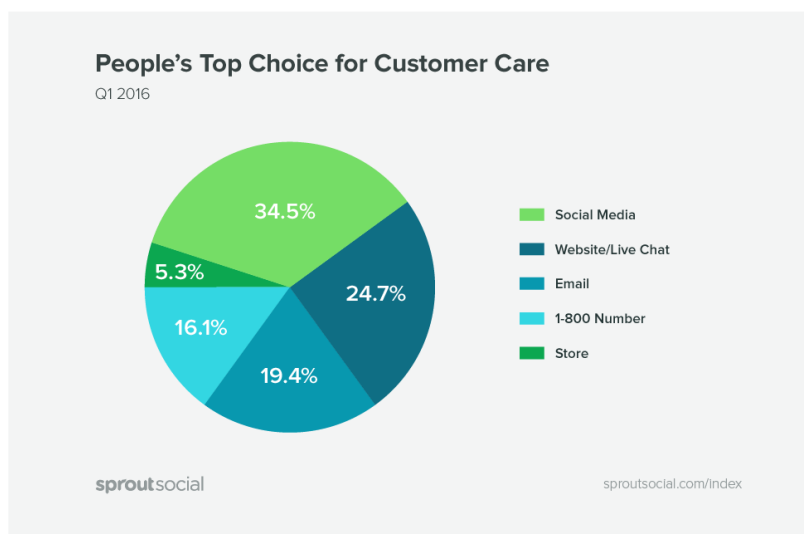

Figure 2

According to Edelman report (2018) Social Media Best for Brand Discovery and Brand Love True even among people who use social media infrequently (weekly or less)

\section{Social Media}

Where I discover or hear about a new brand or product for the first time

Where I most often see and hear things that lead me to fall in love with a brand

Where I most often see and hear things that lead me to fall out of love with a brand

\section{LITERATURE REVIEW}

Victor A. Barger et al. (2015)- contemplated that association between web based systems administration and customer duty. How web based systems administration can be used to utilize purchaser responsibility into exceedingly profitable associations for the two social occasions.

Laurence Dessart et al. (2015)- Investigates that people are taking part in online networks in informal organization stages both with different people and with brands.

Priyanka P. (2015)- contemplated that web-based social networking can be utilized for expanding client steadfastness. With the assistance of persistent client bolster administrations prompts improvement in client maintenance. New applications and social stages will prosper and permit considerably more noteworthy personalization and ongoing, area based commitment in media. 
Shani Yang et al. (2015)- Despite the fact that organizations use internet based life stages, for example, Facebook to draw in with clients, they frequently treat web based life components and other web-based showcasing exercises, for example, web index publicizing as remain solitary, instead of part of a coordinated online exercises framework.

Melissa Clark \& Joanna Mclancon (2013)- In their examination have set up through a relapse investigation that clients of an association, who like or pursue the association's web based life page, see the more elevated amount of relationship venture than the individuals who were no devotees. It prompts the higher impression of relationship quality, the more elevated amount of consumer loyalty and faithfulness.

Ates Bayazit Hayta (2013)- Contemplated that internet-based life is on the most vital devices correspondence channels. Buyers do access to data about stock and dare to be gotten by requiring by techniques for web-based life in a manner of speaking.

Tesfaye Nekatibeb (2012)- Examined online life gives focal points of whole deal duty among brands and customers in like manner allowed to everyone to bestow sufficiently and gainfully in a way uncommon by some other media it very well may be considered as the specific instrument of the propelled period

Joshua Stein (2012)- Contemplated that customer connect with any brand on these internet based life stages. Purchasers sincerely joined the brand.

Linda Hollebeek (2011)- Concentrate to setting ward and brand-related by particular levels of subjective, enthusiastic and social movement in brand communications.

Mehmood Rehmani (2011)- Considered due to web based life it was less demanding for internet business advertisers to discuss straightforwardly with their intended interest groups. This is because of individuals can take finish data of item additionally make correlation with various brands which results to purchasing of item according to decision which prompts mark responsibility. Study investigated because of expanding number of cell phone clients and web clients, individuals have a tendency to get impact for acquiring of items.

Wenhong Luo \& QB Chung (2010)- Endeavored to think about the connection between online retailer notoriety and their internet estimating techniques, in this manner investigating regarding why online value scattering exists on examination shopping administrations.

R.A.Gbadeyan (2010)- ponder inspected that there are open doors for organizations in the market, organizations can develop with the assistance of online life showcasing. Employments of SNS investigated that association can do coordinate showcasing for online informal organization there are individuals who invest more energy in SNS. Concentrate additionally finds the purposes behind individuals were utilizing person to person communication destinations due tosafety concerned reason, in fact inability because of absence of trust in utilizing web, scholarly rejecters who feel exercise in futility.

Russell S. Winer (2008)-depicted the various types of new media which was utilized by organizations to draw in clients that is person to person communication destinations like Facebook, Myspace, Second Life, and You Tube, etc have made perhaps the most consideration and besides depict difficulties that these media were accessible from the perspectives of the advancing boss where Marketers have been watchful in using this new medium in perspective on the peril that people from a system will end up irritated from an over-commercialization of the site. 


\section{OBJECTIVES}

- The essence of this study to determine the dimensions of social media.

- To study the conversions, responsiveness and Clicks/Impression in Social Media.

Ash, T., M. Ginty, and R. (2012) - that the change activities are quantifiable occasions on the web based life systems locales, which moved their guests towards exercises and business objectives. In this manner, the change activities will rely upon the online life systems website type. While, the prompt transformation rate count depends on the level of the quantity of guests of internet based life organizing locales, which start (suspects) and finish (clients) the whole procedure of the lead age.

Lin et al., (2015) - research demonstrates that responsiveness improves mark correspondence, makes mark character, and expands mark value. Responsiveness catches how buyers react to a brand's online exercises and how they collaborate with brands on the brand's web based life outlets. Contrasted with discussion among customers, responsiveness alludes to the connection among shoppers and firms.

The alliance, discussion, and responsiveness moderate the effect of notice rank on active visitor clicking percentage and change rate. Past research demonstrates that online query output positions impact promoting viability. to tap on the commercial and make a buy will increment. In particular, a brand with high brand commitment via web-based networking media should support the impact of result rank on web search tool publicizing viability (Pan et al., 2007; Westerwick, 2013).

\section{CONCLUSIONS}

The measure of online networking clients that play out an activity you want, such as agreeing to accept your pamphlet, downloading a digital book, or purchasing your item.

Changes is a famous web based promoting term, and much progressively vital for online networking explicitly On Social media, it is less demanding for a brand to customize each message or association to every client they have contact with. They can without much of a stretch know when clients talk about their image, they can respond to it (regardless of whether it is great or awful) and they approach loads of data about their clients. On Social media stages, organizations can communicate with clients all through every one of the means of a buy: previously, amid and after the buy.

\section{REFERENCES}

1. Ates Bayazit Hayta. (2013). A study on the effects of social media on young consumers buying behaviours, European Journal of Research on Education, 2013, Special Issue: Human Resource Management, 65-74.

2. Ash, T., M. Ginty, and R. Page. 2012. Landing Page Optimization: The Definitive Guide to Testing and Tuning for Conversions. 2 nd ed. Indianapolis: John Wiley \& Sons

3. Blackshaw, P., \& Nazzaro, M. (2006). Consumer-generated media (CGM) 101: Word-of-mouth in the age of the web-fortified consumer. New York: Nielsen BuzzMetrics.

4. Bourdieu, P. (1986). The forms of capital. In John G. Richardson (Ed.) Handbook of Theory and Research for the Sociology of Education, New York: Greenwood Press. 
5. Ghose, A., Ipeirotis, P. G., \& Li., B. (2014). Examining the impact of ranking on consumer behavior and search engine revenue. Management Science, 60(7), 1632-1654.

6. Gretzel, U. (2006). Consumer generated content - trends and implications for branding. e-Review of Tourism Research, 4(3), 9-11.

7. Joshua Stein. (2012). The Relationship Between Social Media Use and Consumer Brand Engagement, Journal of Undergraduate Research at Minnesota State University, Mankato, Vol. 12, Article 11.

8. Kozinets, Robert V. (2014), “Social Brand Engagement: A New Idea,” Gfk Marketing Intelligence Review, 6 (2), 9-15.

9. Lin, S., Ross, W.J., \& Liu, H. (2015). Does the social value of a brand matter? An empirical investigation of the impact of brand social engagement on firm's financial performance

10. Laurence Dessart, Cleopatra Veloutsou and Anna Morgan. (2015). Consumer engagement in online brand communities, Journal of Product \& Brand Management, 24/1 (2015) 28-42.

11. Linda Hollebeek. (2011). Exploring Customer Brand Engagement: definition \& Themes, Journal of Strategic Marketing,Vol. 19, No. 7, December 2011, 555-573.

12. Melissa Clark, \& Joanna Melancon. (2013). The Influence of Social Media Investment on Relational Outcomes, International Journal of Marketing Studies, Vol. 5, No. 4; 2013. 5,(4).

13. Mehmood Rehmani and Muhammad Ishfaq Khan. (2011). The Impact of E-Media on Customer Purchase Intention, International Journal of Advanced Computer Science and Applications, Vol. 2, No.3, March 2011.

14. Millen, D. R., \& Patterson, J. F. (2002). Stimulating social engagement in a community network. In Proceedings of the 2002 ACM conference on Computer Supported Cooperative Work, 306-313.

15. Priyanaka Pandey. (2015). Social Media increases Customer Loyalty. 34,(1), 9-12.

16. Pan, B., Hembrooke, H., Joachims, T., Lorigo, L., Gay, G., \& Granka, L. (2007). In Google we trust: Users' decisions on rank, position, and relevance. Journal of Computer-Mediated Communication, 12(3), 801-823

17. Russell S. Winer. (2008). New Social Communications Approaches in Marketing: Issues and Research Directions, Journal of Marketing Science Institute New York University, 50-68.

18. Shuai Yang, Shan Lin, Jeffery R Carlson and William T. Ross jr. (2015). Brand Engagement on social: will firms social media efforts influence search engine advertising effectiveness, Journal of Marketing Management, Volume 32, pages 526-557.

19. Tesfaye Nekatibebe. (2012). Evaluating the Impact of Social Media on Traditional Marketing, Journal of International Business and Logistics, volume 35, pages 20-51.

20. Victor A. Barger, James W. Peltier, and Don E. Schultz (2016), "Social media and consumer engagement: A review and research agenda," Journal of Research in Interactive Marketing, 10(4), 268-287.

21. Wenhong Luo, \& QB Chung. (2010). Retailer Reputation \& Online Pricing Strategy, Journal of Computer Information Systems, 50(4),50-56.

22. Weinberg, B. D., \& Pehlivan, E. (2011). Social spending: Managing the social media mix. Business Horizons, 54 (3), $275-282$.

23. Xiang, Z., \& Gretzel, U. (2010). Role of social media in online travel information search. Tourism Management, 31(2), 179188. 
24. Weinberg, B. D., \& Pehlivan, E. (2011). Social spending: Managing the social media mix. Business Horizons, 54 (3), $275-282$.

25. Zhang, S., Jiang, H., \& Carroll, J. M. (2011). Integrating online and offline community through Facebook. Collaboration Technologies and Systems (CTS), 2011 International Conference,569-578.

26. Book ( IAN P. Buckinggham) 